\title{
Preparation and Voltammetric Characterization of Electrodes Coated with Langmuir-Schaefer Ultrathin Films of Nafion ${ }^{\circledR}$
}

\author{
Paolo Bertoncello ${ }^{b}$ and Paolo Ugo ${ }^{*, a}$ \\ ${ }^{a}$ Department of Physical Chemistry, University of Venice, S. Marta 2137, 30123 Venice, Italy \\ ${ }^{b}$ Department of Biophysics, M\&O Science and Technologies, University of Genoa, Corso Europa 30, \\ 16132 Genoa, Italy
}

\begin{abstract}
Filmes ultrafinos do polímero perfluorado Nafion ${ }^{\circledR}$ foram depositados em eletrodos de óxido índio-titânio (ITO) usando a técnica de Langmuir-Scaefer (LS), depois da otimização das condições de composição da subfase. As características morfológicas das camadas foram obtidas por Microscopia de Força Atômica (AFM). Filmes de Nafion ${ }^{\circledR}$ LS mostraram boa uniformidade e cobertura completa da superfície do eletrodo. No entanto, diferentes graus de organização das camadas poliméricas ficaram evidentes com respeito a filmes finos depositados por revestimento rotacional. Eletrodos ITO modificados com camadas de Nafion ${ }^{\circledR}$ LS, pré-concentrados por cátions eletroativos de troca iônica, como o $\mathrm{Ru}\left[\left(\mathrm{NH}_{3}\right)_{6}\right]^{3+}$, dissolveram-se em soluções diluídas. A espécie eletroativa foi retida pelo ITO com camada de Nafion ${ }^{\circledR}$ LS, mesmo depois da mudança do eletrodo modificado para eletrodo de suporte purificado. Isto possibilitou o uso do complexo de rutênio como padrão voltamétrico para o teste do fenômeno de difusão nos filmes de Nafion $^{\circledR}$ LS. Os coeficientes de difusão aparentes $\left(\mathrm{D}_{\text {app }}\right)$ do $\mathrm{Ru}\left[\left(\mathrm{NH}_{3}\right)_{6}\right]^{3+}$ incorporado no filme de $\mathrm{Nafion}^{\circledast} \mathrm{LS}$ foram obtidos por medidas voltamétricas. Os valores de $\mathrm{D}_{\text {app }}$ diminuíram levemente com o aumento da quantidade de complexo de rutênio incorporado no filme ultrafino e foram significativamente mais baixos do que os valores para filmes de Nafion ${ }^{\circledR}$ recapados, em acordo com a natureza altamente condensada dos filmes de Nafion ${ }^{\circledR}$ LS.
\end{abstract}

Ultrathin films of Nafion ${ }^{\circledR}$ perfluorinated polymer were deposited on indium-tin oxide electrodes (ITO) by using Langmuir-Schaefer (LS) technique, after optimization of the subphase composition conditions. Morphological characteristics of these coatings were obtained by Atomic Force Microscopy (AFM). Nafion ${ }^{\circledR}$ LS films showed a good uniformity and complete coverage of the electrode surface, however a different organization degree of the polymer layer was evidenced with respect to thin films deposited by spin-coating. ITO electrodes modified with Nafion ${ }^{\circledR}$ LS coatings preconcentrate by ion-exchange electroactive cations, such as $\mathrm{Ru}\left[\left(\mathrm{NH}_{3}\right)_{6}\right]^{3+}$, dissolved in diluted solutions. The electroactive species is retained by the Nafion ${ }^{\circledR}$ LS coated ITO also after transfer of the modified electrode into pure supporting electrolyte. This allowed the use of the ruthenium complex as voltammetric probe to test diffusion phenomena within the Nafion ${ }^{\circledR}$ LS films. Apparent diffusion coefficients $\left(\mathrm{D}_{\text {app }}\right)$ of $\mathrm{Ru}\left[\left(\mathrm{NH}_{3}\right)_{6}\right]^{3+}$ incorporated in Nafion ${ }^{\circledast} \mathrm{LS}$ films were obtained by voltammetric measurements. $\mathrm{D}_{\text {app }}$ values decrease slightly by increasing the amount of ruthenium complex incorporated in the ultrathin film. They are significantly lower than values typical for recasted Nafion ${ }^{\circledR}$ films, in agreement with the highly condensed nature of the Nafion ${ }^{\circledR}$ LS fims.

Keywords: Langmuir-Schaefer films, Nafion ${ }^{\circledR}$, modified electrodes, $\mathrm{Ru}\left[\left(\mathrm{NH}_{3}\right)_{6}\right]^{3+}$, diffusion coefficients

\section{Introduction}

Nafion $^{\circledR}$, a copolymer of tetrafluoroethylene and sulfonyl fluoride vinyl ether, is one of the most interesting solid polymer electrolytes for technological and scientific researches. It is used as ionomeric permselective membrane

* e-mail: ugo@unive.it for a variety of electrochemical applications including fuel cells, water electrolyzers and chlor-alkali cells, ${ }^{1,2}$ chemically modified electrodes, ${ }^{3-5}$ ion-selective and potentiometric sensors, ${ }^{6-7}$ voltammetric sensors ${ }^{8-9}$ and electrochromic devices. ${ }^{10-11}$

For electroanalytical purposes, Nafion ${ }^{\circledR}$ coated electrodes has been prepared mainly by depositing a film of the polymer recasted from water-alcohol solutions. ${ }^{8}$ Such 
modified electrodes were widely used for preconcentrating and determining trace concentrations of electroactive cations..$^{8-9}$ Voltammetric signals relevant to the preconcentrated analytes are, in fact, increased by a factor dependent on the partitioning within the film. ${ }^{8}$ However, the much lower values for the apparent diffusion coefficients which rule mass and charge transport phenomena within the coating, ${ }^{4,5}$ can sometimes contrast the increase in sensitivity expected only on the basis of preconcentration effects.

In general, fluorocarbon polymers are hydrophobic in nature, but $\mathrm{Nafion}^{\circledR}$ is an exception due to its partial solubility in water determined by the presence of sulphonic groups, which exhibit a very strong acidic character. The water content of the membrane affects greatly its properties, since it determines the type of counter ions incorporated within the polymer matrix ${ }^{12,13}$ as well as the dynamics of diffusive processes within the coating layer. ${ }^{4}$ Also the ionic conductivity in Nafion ${ }^{\circledR}$ is understood to be strongly dependent on the morphology and local structural order of the film. ${ }^{14}$ All these evidences support the relevancy of developing deposition methods able to control the film architecture down to the molecular level.

Langmuir-Blodgett (LB), Langmuir-Schaefer (LS), and layer-by-layer self-assembly techniques ${ }^{15}$ allow one to prepare ordered molecular architectures where thickness is controllable up to the molecular level. ${ }^{16}$ In a recent paper, ${ }^{11}$ we showed that by choosing proper composition of the subphase it was possible to obtain Langmuir monolayers of Nafion ${ }^{\circledR}$ at the water/air interface and that this films can be deposited on solid substrates by LS technique. At variance with "classical" LB technique, in the LS deposition the substrate is placed horizontally (instead of vertically) in contact with the Langmuir monolayer film. When the substrate is lifted and separated from the water surface, the monolayer is transferred onto the substrate. ${ }^{15}$ In the present work we examine in detail the charge transfer and diffusion behavior of electroactive probe based on cations such as $\mathrm{Ru}\left[\left(\mathrm{NH}_{3}\right)_{6}\right]^{3+}$, incorporated by ion-exchange in Nafion ${ }^{\circledR} \mathrm{LS}$ films deposited on electrode surfaces in comparison with "traditional" coatings deposited by solvent evaporation of recasted Nafion ${ }^{\circledR}$ solutions. ${ }^{3,4,18}$

\section{Experimental}

\section{Fabrication of Langmuir-Schaefer films of Nafion ${ }^{\circledR}$}

Nafion ${ }^{\circledR} 117$ solution $(5 \% \mathrm{~m} / \mathrm{v}$ in a mixture of low molecular weight alcohol) was purchased from SigmaAldrich. All other chemicals were of reagent grade quality. A stock solution of Nafion ${ }^{\circledR}$ was prepared by dilution of the commercial solution with $\mathrm{CH}_{3} \mathrm{OH}$ to obtain a final concentration of $0.5 \mathrm{mg} \mathrm{cm}^{-3}$. On the basis of the methanol/ water solvent ratio used in this study, $\mathrm{Nafion}^{\circledR}$ is expected to attain a micellar conformation with the polar sulfonate groups located on the surface of the micelles and the hydrophobic fluorocarbon chains in the inner part. The Nafion ${ }^{\circledR}$ Langmuir monolayer was formed by using a Langmuir trough (MDT corporation, Moscow, Russia - $240 \mathrm{~mm}$ x $100 \mathrm{~mm}$ or, alternatively, with a KSV LangmuirBlodgett trough). The surface pressure was measured by means of a Wilhemy balance with an accuracy of $0.2 \mathrm{mN} \mathrm{m}^{-1}$. The volume of Nafion ${ }^{\circledR}$ solution added to the subphase was varied in the range of $100-200 \mu \mathrm{L}$. An elapsed time of two to five minutes was given before compression of the floating film. The effect of ions on the Langmuir monolayer formation was studied by using subphases containing various ions, i.e., pure water, $\mathrm{NaCl}, \mathrm{LiClO}_{4}, \mathrm{NaCl}$ $+\mathrm{HCl}(\mathrm{pH} 2), \mathrm{HCl}(\mathrm{pH} 2)$ water solutions, respectively. Preparation and optimization of these subphases was described elsewhere. ${ }^{11}$ A large number of deposition parameters influences the microstructure and the growth rate of the Nafion ${ }^{\circledR}$ LS film. Based on Langmuir behavior, the conditions of parameters used for the deposition are: surface pressure of $25 \mathrm{mN} \mathrm{m}^{-1}$ and $0.1 \mathrm{~mol} \mathrm{dm}^{-3} \mathrm{NaCl}$ solution as the subphase.

\section{Atomic force microscopy}

Atomic force microscopy (AFM) was performed by using a Digital Instruments D3100 AFM with Nanoscope IIIa controller operating in air at a constant relative humidity of about $60 \%$. The AFM worked in "Tapping Mode" configuration using commercial $\mathrm{n}^{+}$-doped silicon microlevers with an apex curvature radius of the probe tip in the range 5-10 nm and a typical force constant of about $40 \mathrm{~N} \mathrm{~m}^{-1}$. AFM technique was also used for the estimation of the films thickness by using the following procedure. At first the film was repeatedly scratched using a cantilever of the same type used for imaging but operating in "contact mode". The typical amount of force applied for a complete removal of the material deposited was in the range $2-5 \mu \mathrm{N}$. This values have been chosen in order to discover a clean area of the substrate and to avoid the substrate damaging. A new probe was then used to scan the scratched area. The film thickness was then obtained by averaging several profiles of the scratched area and considering the vertical distance between the discovered substrate and the film surface.

\section{Electrochemical measurements}

Cyclic voltammetry measurements were performed 
using a EG\&G PARC, model 263A or a CH model 620 A potentiostat/galvanostat controlled by their own software. In all cases a standard three electrodes cell configuration was used. The working electrode was an ITO (Indium Tin Oxide) coated glass plate on which Nafion ${ }^{\circledR}$ LS films were deposited. A platinum coil was used as the counter electrode and $\mathrm{Ag} / \mathrm{AgCl}(\mathrm{KCl}$ saturated) as the reference electrode. The working electrode area immersed in the electrolyte solution was kept equal to $0.6 \mathrm{~cm}^{2}$. All solutions were accurately degassed with nitrogen before the measurements.

\section{Results and Discussion}

\section{Langmuir isotherms}

Figure 1 reports the pressure-area isotherm of Nafion ${ }^{\circledR}$ molecules at the air-water interface in subphases containing different electrolytes. As shown by curve 1 in Figure 1, no sharp increase in the pressure-area plot characterizes the isotherm obtained in pure water. This indicates the sinking of some of the molecules below the air/water interface due to the partial solubility of Nafion ${ }^{\circledR}$ in pure water. However, the shape of the isotherms changes dramatically when strong electrolytes are dissolved in the subphase (see Figure 1, curve 2-5). Such marked variations in the pressure-area isotherms of Nafion ${ }^{\circledR}$ Langmuir monolayers indicate that the polymer undergoes relevant structural changes connected with the high ionic strength of the subphases and related to the electrostatic shielding effect that cations dissolved in the subphase can play with respect to the sulfonated groups of the polymer. These cations can stabilize, in fact, the interfacial film by lowering the ionic repulsion between the sulfonic groups of Nafion ${ }^{\circledR}$ which are put very close each other during the compression of the layer.

In these cases, for example with $\mathrm{Na}^{+}$in the subphase (see curve 2 in Figure 1), Nafion ${ }^{\circledR}$ does not sink, as in pure water, rather it floats at the air/water interface. A smooth phase transition with an increase in surface pressure above $10 \mathrm{mN} \mathrm{m}^{-1}$ is observed from all curves $2-5$ in Figure 1. During the solid phase transition the polymer molecules start to interact closely increasing their 2-D packing degree. The further increase in the surface pressure above $45 \mathrm{mN} \mathrm{m}^{-1}$ shows the occurrence of 3-D transformations with the collapsing of the interfacial film at $50-60 \mathrm{mN} \mathrm{m}^{-1}$. These transformations were previously put in evidence by Brewster Angle Microscopy. ${ }^{11}$

The comparison of the different isotherms shown in Figure 1, indicates that the degree of condensation of the film depends on the specific interactions between Nafion ${ }^{\circledR}$ and the cations dissolved in the subphase. In particular,

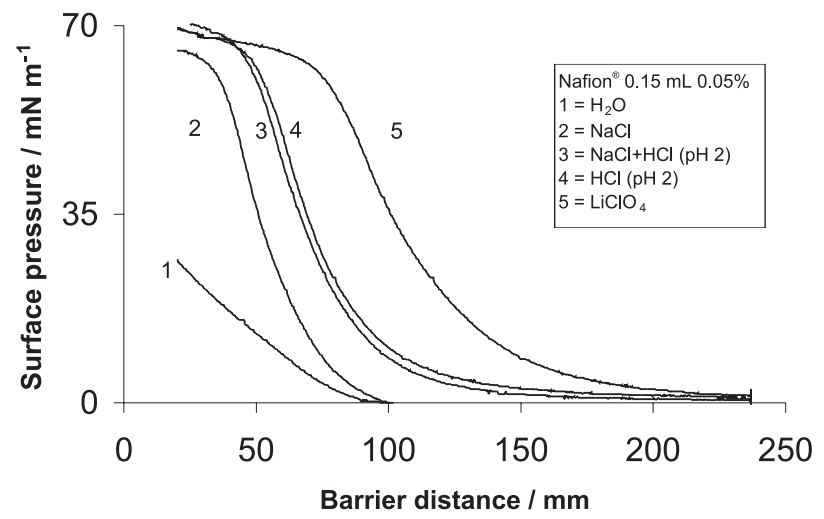

Figure 1. Pressure-Area ( $\Pi-A)$ isotherms of Nafion ${ }^{\circledR}$ in different subphases at $1.67 \mathrm{~mm} \mathrm{~s}^{-1}$ barrier speed: (1) $\mathrm{H}_{2} \mathrm{O}$, (2) $0.1 \mathrm{~mol} \mathrm{dm}^{-3}$ $\mathrm{NaCl}$, (3) $0.1 \mathrm{~mol} \mathrm{dm}^{-3} \mathrm{NaCl}+\mathrm{HCl}(\mathrm{pH} 2)$; (4) $\mathrm{HCl}(\mathrm{pH} 2)$, (5) 0.1 $\mathrm{mol} \mathrm{dm} \mathrm{LiClO}_{4}$.

the evidence that the condensation extent follows the sequence $\mathrm{Na}^{+}>\mathrm{H}^{+}>\mathrm{Li}^{+}$indicates a correlation with the sequence reported in the literature for the ion-exchange selectivity of Nafion ${ }^{\circledR}$ for these ions. ${ }^{19}$ This indicates that the same factor which favours the ion-exchange incorporation in membranes could switch also the aggregation of interfacial films produced by Langmuir compression.

Note that, due to difficulties in determining the real molecular weight and the exact solubility of the available Nafion $^{\circledR}$, the isotherms report the barrier distance as the quantity on the X-axis. The stability of the Langmuir film at the air-water interface depends strongly on the selection of suitable subphases and barrier speeds as well as the concentration of the Nafion ${ }^{\circledR}$ solutions. Based on the behaviours of the pressure-area isotherms curves, $25 \mathrm{mN}$ $\mathrm{m}^{-1}$ was estimated as the best value for performing the deposition of LS films, since at this surface pressure a stable 2-D transformation is evident.

\section{Atomic force microscopy}

Figure 2 shows typical AFM images of Nafion ${ }^{\circledR}$ LS films. Figure 2a, which refers to a five layers sample, is representative of the surface morphology of these films. The whole substrate surface is covered uniformly. By increasing the number of layers deposited the films thickness increases linearly from $1.3 \mathrm{~nm}$ for one layer to $16 \mathrm{~nm}$ for 10 layers, while the average grain-size increases from $25 \mathrm{~nm}$ to $70 \mathrm{~nm}$. The increase in the number of layers deposited reflects also in the increase of the surface roughness factor $(\mathrm{Rq})$ from $0.5 \mathrm{~nm}$ to $1.2 \mathrm{~nm}$.

Figure $2 \mathrm{~b}$ shows a typical AFM topography of Nafion ${ }^{\circledR}$ thin films deposited by spin-coating at $750 \mathrm{rpm}$. The thickness of the spin-coated film shown in Figure $2 b$ is 


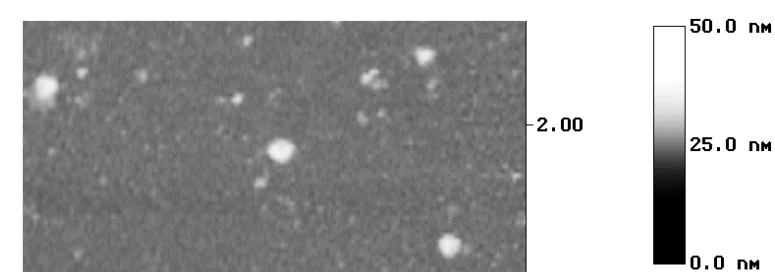

a
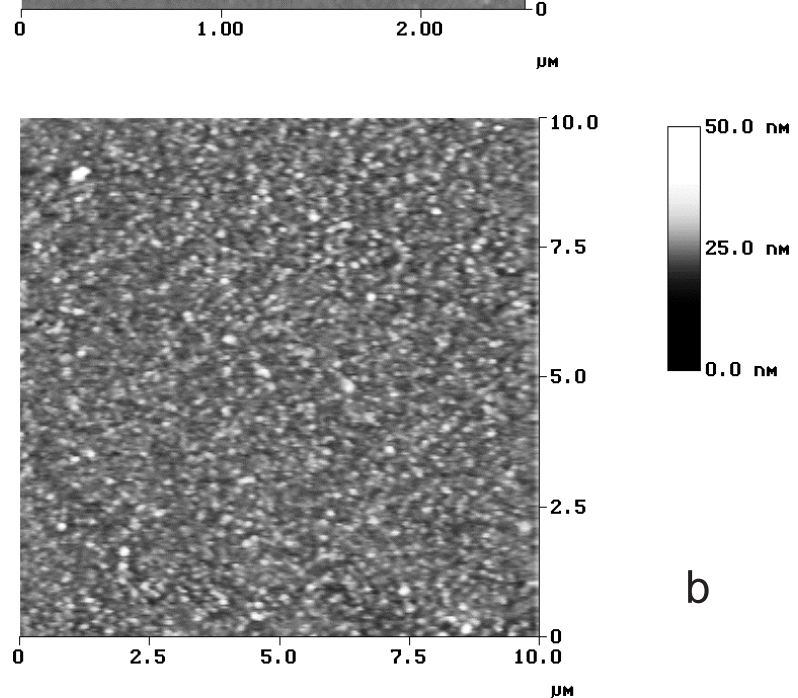

b

Figure 2. AFM pictures of 5 layers of Nafion ${ }^{\circledR}$ LS films (a) deposited on silicon substrate in $0.1 \mathrm{~mol} \mathrm{dm}^{-3} \mathrm{NaCl}$ as subphase; (b) Nafion $^{\circledast}$ spin-coated film on silicon substrate at $750 \mathrm{rpm}$.

equal to $17 \mathrm{~nm}$ and compares with that of a 10 layers Nafion ${ }^{\circledR}$ LS coating. However, the surface roughness factor for spin-coated Nafion ${ }^{\circledR}$ is higher, being equal to $1.8 \mathrm{~nm}$. These evidences indicate a high condensation degree and compactness for Nafion ${ }^{\circledR}$ LS films, while spin-coated films of comparable thickness appear more grainy and rough.

\section{Cyclic voltammetry}

It is well known that Nafion ${ }^{\circledR}$ can incorporate electroactive cations by ion exchange..$^{4,5,18}$ This incorporation (or doping) process allowed dramatic improvements in detection capabilities and electrocatalytic applications of Nafion ${ }^{\circledR}$ coated electrodes with respect to conventional uncoated electrodes. ${ }^{8,9}$ However, it was shown that the properties of recasted Nafion ${ }^{\circledR}$ films depend strongly on the deposition conditions, ${ }^{19,20}$ some of which can not be controlled easily.

In order to investigate if Nafion ${ }^{\circledR}$ LS films display preconcentration capabilities similar to those of recasted films and to understand which are the mechanisms which control transport phenomena within these films, the ionexchange and electrochemical behavior of $\mathrm{Ru}\left[\left(\mathrm{NH}_{3}\right)_{6}\right]^{3+}$ incorporated in Nafion ${ }^{\circledR}$ LS films was studied by cyclic voltammetry $(\mathrm{CV})$. At first, the modified electrode was dipped in $10^{-2} \mathrm{~mol} \mathrm{dm}^{-3} \mathrm{NaNO}_{3}$ solution containing a rather low concentration a redox cation, namely $10^{-5} \mathrm{~mol} \mathrm{dm}^{-3}$ $\mathrm{Ru}\left[\left(\mathrm{NH}_{3}\right)_{6}\right]^{3+}$. Cyclic voltammograms recorded in the $\mathrm{Ru}\left[\left(\mathrm{NH}_{3}\right)_{6}\right]^{3+}$ containing solution (not shown) were characterized by a quick increase of the peak currents typical for the $\mathrm{Ru}\left[\left(\mathrm{NH}_{3}\right)_{6}\right]^{3+} / \mathrm{Ru}\left[\left(\mathrm{NH}_{3}\right)_{6}\right]^{2+}$ couple (see below) until a stable signal was obtained after about 5 min. This agrees with a quick ion-exchange preconcentration of the ruthenium complex within the Nafion ${ }^{\circledR}$ LS coating. It is worth to note that at electrodes coated with recasted Nafion ${ }^{\circledR}$ films ion-exchange equilibrium conditions are achieved only after hours. ${ }^{18}$

Figure 3 and 4 show the $\mathrm{CV}$ patterns recorded at an ITO electrode covered with Nafion ${ }^{\circledR}$ LS films, loaded in $\mathrm{Ru}\left[\left(\mathrm{NH}_{3}\right)_{6}\right]^{3+}$ solution and transferred into pure supporting electrolyte $\left(10^{-2} \mathrm{~mol} \mathrm{dm}^{-3} \mathrm{NaNO}_{3}\right)$. Note that soon after transfer signals decrease slightly (about 10\%), but after few minutes, they reach the stable voltammetric behavior shown in Figures 3 and 4.

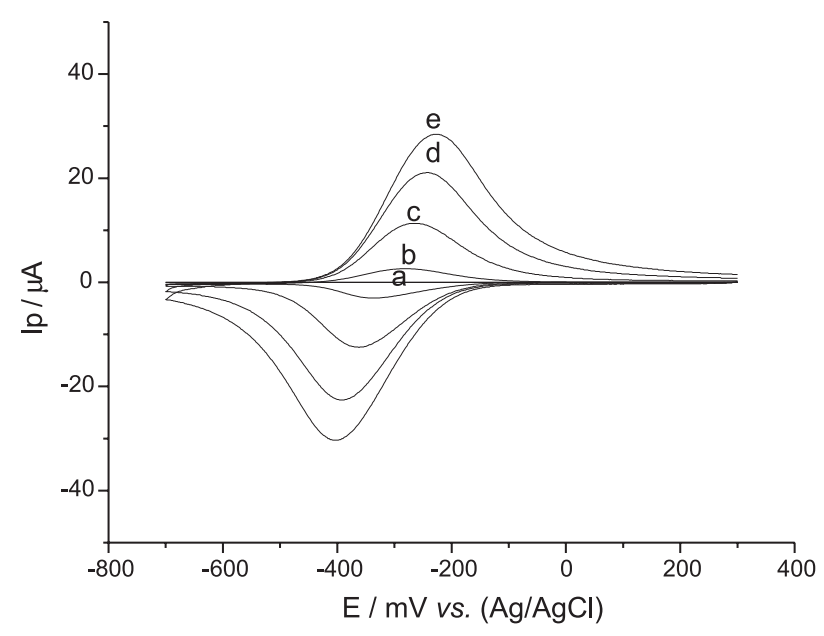

Figure 3. CVs on ITO coated with 30 layers of Nafion ${ }^{\circledR}$ LS films, recorded at different scan rates in $10^{-2} \mathrm{~mol} \mathrm{dm}^{-3} \mathrm{NaNO}_{3}$ supporting electrolyte. The coated ITO were previously loaded in $10^{-5} \mathrm{~mol} \mathrm{dm}^{-3}$ $\mathrm{Ru}\left[\left(\mathrm{NH}_{3}\right]_{6}\right]^{3+}, 10^{-2} \mathrm{~mol} \mathrm{dm}^{-3} \mathrm{NaNO}_{3}$ and then transferred in pure supporting electrolyte. Scan rates: (a) $5 \mathrm{mV} \mathrm{s}^{-1}$, (b) $10 \mathrm{mV} \mathrm{s}^{-1}$, (c) $50 \mathrm{mV} \mathrm{s}^{-1}$, (d) $100 \mathrm{mV} \mathrm{s}^{-1}$, (e) $150 \mathrm{mV} \mathrm{s}^{-1}$.

The CVs in Figure 3 show the scan rate dependence of signals at an ITO electrode coated with 30 layers (45 nm thickness from AFM measurements ) of Nafion ${ }^{\circledR}$ LS films. $\mathrm{E}_{1 / 2}$ values are calculated as $\mathrm{E}_{1 / 2}=\left(\mathrm{E}_{\mathrm{p}}^{\mathrm{f}}+\mathrm{E}_{\mathrm{p}}{ }^{\mathrm{b}}\right) / 2,{ }^{21}$ where $\mathrm{E}_{\mathrm{p}}^{\mathrm{f}}$ and $\mathrm{E}_{\mathrm{p}} \mathrm{b}$ are the voltammetric peak potentials measured in 
the forward and backward scan, respectively. They are roughly independent on the scan rate and are equal to about $-300 \mathrm{mV}$. This agrees with previous observation ${ }^{19}$ which showed that $\mathrm{Ru}\left[\left(\mathrm{NH}_{3}\right)_{6}\right]^{3+}$ incorporation in Nafion ${ }^{\circledR}$ coatings produces a significant negative shift (of about $150 \mathrm{mV}$, for our case) in the $\mathrm{E}_{1 / 2}$ value of the $\mathrm{Ru}\left[\left(\mathrm{NH}_{3}\right)_{6}\right]^{3+2+}$ couple because the higher oxidation state is more strongly bound by the Nafion ${ }^{\circledR}$ sulfonate groups. Note that $\Delta \mathrm{E}_{\mathrm{p}}$ values are rather large at high scan rates while they decrease down to $10 \mathrm{mV}$ at low scan rates $\left(5 \mathrm{mV} \mathrm{s}^{-1}\right)$. The analyses of peak currents indicates that they depend linearly on the square root of the scan rate for $\mathrm{v}>40 \mathrm{mV} \mathrm{s}^{-1}$, while at lower scan rates they depend linearly on $v$. This evidence indicates a diffusion control for the former data and a thin-layer-like behavior for the latter. ${ }^{21} \mathrm{~A}$ diffusion controlled behavior is observed at coated electrodes when the thickness of the diffusion layer is thinner than the coating thickness; ${ }^{8}$ when the opposite is true (usually at low scan rates), thin-layerlike conditions become operative.

Figure 4 shows the dependence of the voltammetric patterns of $\mathrm{Ru}\left[\left(\mathrm{NH}_{3}\right)_{6}\right]^{3+}$ incorporated in Nafion ${ }^{\circledast} \mathrm{LS}$ coated ITOs as a function of the number of LS layers deposited. All these CVs were recorded at $5 \mathrm{mV} \mathrm{s}^{-1}$, i.e. under thinlayer-like conditions. They clearly show that peak currents

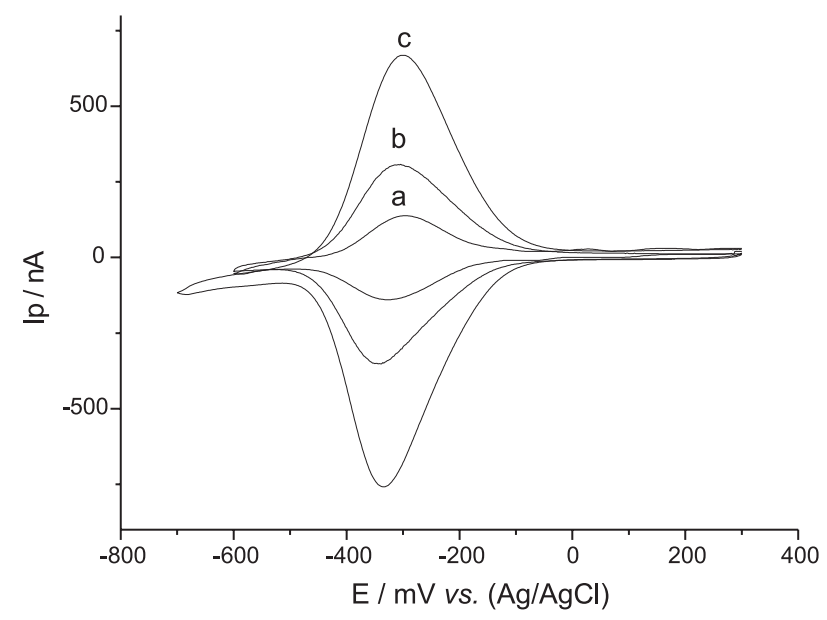

Figure 4. CVs recorded at $5 \mathrm{mV} \mathrm{s}^{-1}$ on ITOs coated with a different number of layers of Nafion ${ }^{\circledR}$ LS films: (a) 5 layers, (b) 10 layers, (c) 20 layers. Other experimental conditions as in Figure 3. scale linearly with the number of layers deposited. The amount of ruthenium complex incorporated in the film is calculated by integrating the area of these voltammetric peak, since under thin-layer-like conditions, the exhaustive electrolyses of all the incorporated species takes place during the voltammetric scan. ${ }^{8}$

For reversible redox couples incorporated in Nafion ${ }^{\circledR}$ coatings, the slope of the $\mathrm{I}_{\mathrm{p}} v s . \mathrm{v}^{1 / 2}$ plot in the diffusion controlled region obeys the Randles-Sevcik equation., ${ }^{8,21}$ The slopes of these plots, when linear, can be combined with known film thickness and amount of electroactive species incorporated (obtained by coulometric integration of $\mathrm{CV}$ peaks under thin-layer conditions, see above) in order to calculate the values of apparent diffusion coefficients $\left(\mathrm{D}_{\text {app }}\right)$ of $\mathrm{Ru}\left[\left(\mathrm{NH}_{3}\right)_{6}\right]^{3+}$ within the coating. ${ }^{9}$

$\mathrm{D}_{\text {app }}$ values were calculated by using equation (1):

$\mathrm{D}_{\text {app }}=\left(S \times \Phi / 2.69 \times 10^{5} \times \mathrm{m}\right)$

where $S=$ slope of $\mathrm{I}_{\mathrm{p}} v s . \mathrm{v}^{1 / 2}$ plots, $\Phi=$ film thickness $(45$ $\mathrm{nm}), m$ is the number of moles of $\mathrm{Ru}\left[\left(\mathrm{NH}_{3}\right)_{6}\right]^{3+}$ incorporated in the film. Note that if the electrode area is kept constant during the low scan rate scan (used for the coulometric measure of $m$ ) and the high scan rates scans (used to measure $S$ ), the exact knowledge of the electrode area has no influence on $\mathrm{D}_{\text {app }}$ estimation.

Typical data measured at Nafion ${ }^{\circledR}$ LS coated ITO are listed in Table 1, as a function of different ruthenium complex loading. $\mathrm{D}_{\text {app }}$ values decreased slightly with increasing the ruthenium loading, however, they are all in the order of $10^{-11} \mathrm{~cm}^{2} \mathrm{~s}^{-1}$. Such values are almost two order of magnitude lower than those reported in the literature for films of recasted Nafion ${ }^{\oplus}$, which ranged from $2 \times 10^{-9}$ to $4 \times 10^{-8} \mathrm{~cm}^{2} \mathrm{~s}^{-1} .4,5,19.22$ Such an evidence agrees with the AFM observation that a more compact and condensed structure characterizes Nafion $^{\circledR}$ LS films with respect to films of comparable thickness recasted by spin-coating. A more condensed film is, in fact, expected to slow down the physical diffusion of electroactive ions. The slight decrease in $\mathrm{D}_{\text {app }}$ values with increasing the ruthenium loading for Nafion ${ }^{\circledR}$ LS films is somehow parallel, although less dramatic, with data obtained for measurements performed

Table 1. Values of apparent diffusion coefficients $\left(\mathrm{D}_{\text {app }}\right)$ for $\mathrm{Ru}\left[\left(\mathrm{NH}_{3}\right)_{6}\right]^{3+}$ in Nafion ${ }^{\circledast} \mathrm{LS}$ films (30 layers) at different ruthenium loadings $(\Gamma)$; $S=$ slope of $\mathrm{I}_{\mathrm{p}} v s . \mathrm{v}^{1 / 2}$ plots, $\Phi=$ film thickness $(45 \mathrm{~nm}), m=$ number of moles of $\mathrm{Ru}\left[\left(\mathrm{NH}_{3}\right)_{6}\right]^{3+}$ incorporated in the film, $\mathrm{C}_{\mathrm{s}}$ and $\mathrm{C}_{\mathrm{p}}$ are the $\mathrm{Ru}\left[\left(\mathrm{NH}_{3}\right)_{6}\right]^{3+}$ concentrations in the loading solution and in the polymer, respectively

\begin{tabular}{|c|c|c|c|c|c|}
\hline $\mathrm{C}_{\mathrm{s}}\left(\mathrm{mol} \mathrm{dm}^{-3}\right)$ & $\Gamma\left(\right.$ moles $\left.\mathrm{cm}^{-2}\right)$ & $S\left(\mathrm{~A} \mathrm{~s}^{1 / 2} \mathrm{~V}^{-1 / 2}\right)$ & $m / \Phi\left(\right.$ moles $\left.\mathrm{cm}^{-1}\right)$ & $\mathrm{C}_{\mathrm{p}}\left(\mathrm{mol} \mathrm{dm} \mathrm{dm}^{-3}\right)$ & $\mathrm{D}_{\text {app }}\left(\mathrm{cm}^{2} \mathrm{~s}^{-1}\right)$ \\
\hline $1 \times 10^{-6}$ & $1 \times 10^{-10}$ & $5.4 \times 10^{-5}$ & $1.3 \times 10^{-5}$ & 0.022 & $2.25 \times 10^{-11}$ \\
\hline $5 \times 10^{-6}$ & $5.8 \times 10^{-10}$ & $7.7 \times 10^{-6}$ & $7.7 \times 10^{-5}$ & 0.120 & $1.4 \times 10^{-11}$ \\
\hline $10 \times 10^{-6}$ & $7.5 \times 10^{-10}$ & $8.6 \times 10^{-5}$ & $10 \times 10^{-5}$ & 0.166 & $1.0 \times 10^{-11}$ \\
\hline
\end{tabular}


on recasted Nafion ${ }^{\circledR}$ films. ${ }^{19,22}$ Such a dependence can be attributed to the electrostatic crosslinking of Nafion ${ }^{\circledR}$ polymer chains caused by the incorporation of cation with ionic charge $>1$. Each $\mathrm{Ru}\left[\left(\mathrm{NH}_{3}\right)_{6}\right]^{3+}$ interacts with $3 \mathrm{SO}_{3}^{-}$ groups of Nafion ${ }^{\circledast}$ possibly coming from different polymer chains which are, therefore, crosslinked. In the case of Nafion ${ }^{\circledast}$ LS coatings such a crosslinking seems to further increase the already high condensation degree of the film.

The comparison between column 1 and 5 in Table 1, shows the very high preconcentration capability of the Nafion ${ }^{\circledR}$ LS coating. The partitioning of the analyte quantified by $\mathrm{C}_{\mathrm{p}} / \mathrm{C}_{\mathrm{s}}$ ratios (where $\mathrm{C}_{\mathrm{p}}$ and $\mathrm{C}_{\mathrm{s}}$ are the analyte concentrations in the polymer and in the solution, respectively) is in fact in the order of $10^{4}$. This explains why, notwithstanding the rather low $\mathrm{D}_{\text {app }}$ values, high peak currents and well resolved voltammograms are observed at electrodes coated with Nafion ${ }^{\circledR}$ LS films even when the loading is performed in micromolar solution concentrations of electroactive analytes. Note that a similar behavior was observed for Nafion ${ }^{\circledR}$ LS films incorporating methylviolgen as electroactive probe cation. ${ }^{11}$

\section{Conclusions}

AFM and CV measurements indicate that Nafion ${ }^{\circledR}$ LS films deposited on ITO form continuous films whose thickness depends on the number of layers deposited. These films are more compact and present a higher molecular condensation degree than recasted and spin-coated films. Nafion ${ }^{\circledR}$ LS films can preconcentrate electroactive cations and such a process is faster than at electrodes coated with recasted Nafion ${ }^{\circledR}$ films. The electroactivity of incorporated $\mathrm{Ru}\left[\left(\mathrm{NH}_{3}\right)_{6}\right]^{3+}$ at relatively high scan rates $\left(>40 \mathrm{mV} \mathrm{s}^{-1}\right)$ is ruled by a very small apparent diffusion coefficient which indicates charge transport phenomena slower than in recasted films. However, the amplification of signals related to the analyte incorporation in the coating still prevails so allowing one to use Nafion ${ }^{\circledR}$ LS coated electrodes for the preconcentration and ion-exchange voltammetric determination of electroactive cations present at micromolar solution concentrations.

\section{Acknowledgments}

The authors thank Andrea Notargiacomo (Università di Roma Tre) and Francesca Vezzà for performing some experiments. Partial financial support by MIUR (Rome) is acknowledged.

\section{References}

1. Xing, B.; Savadogo, O.; Electrochem. Commun. 2000, 2, 697

2. Pillai, K.C. ; Kumar, A.S. ; Zen, J.-M.; J. Mol. Catal. A: Chem. 2000, 160, 277

3. White, H.S.; Leddy, J.; Bard, A.J.; J. Am. Chem. Soc. 1982, 104,4811

4. Martin, C.R.; Dollard, K.A.; J. Electroanal. Chem. 1983, 159, 127

5. Buttry, D.A.; Anson, F.C.; J. Electroanal. Chem. 1981, 130, 333

6. Martin, C.R.; Freiser, H.; Anal. Chem. 1981, 53, 902

7. Ugo, P.; Moretto, L.M.; De Boni, A.; Scopece, P.; Mazzocchin, G.A.; Anal. Chim. Acta 2002, 474, 147

8. Ugo, P.; Moretto, L.M.; Electroanalysis 1995, 7, 1105

9. Ugo, P.; Moretto, L.M.; Vezzà, F.; ChemPhysChem 2002, 3, 917

10. Sabatani, E.; Nikol, H.D.; Gray, H.B.; Anson, F.C.; J. Am. Chem. Soc. 1996, 118, 1158

11. Bertoncello, P.; Ram, M.K.; Notargiacomo, A.; Ugo, P.; Nicolini, C.; Phys. Chem. Chem. Phys., 2002, 4, 4036

12. Gebel, G.; Lombard, J.; Macromolecules 1997, 30, 7914

13. Mauritz, K.A.; Mater. Sci. Eng., C 1998, 6 , 121

14. Okada, T.; Moller-Holst, S.; Gorseth, O.; Kjelstrup, S.; J. Electroanal. Chem., 1998, 442, 137

15. Ulman, A.; Ultrathin Organic Films, Academic Press: New York, 1991

16. Ram, M.K.; Nicolini, C.; Rec. Res. Devel. Phys. Chem. 2000 , 4, 219

17. Steck, A.; Yeager, H.L.; Anal .Chem. 1980, 52, 273

18. Szentirmay, M.N.; Martin, C.R.; Anal. Chem. 1984, 56, 1898.

19. Shi, M.; Anson, F.C.; Anal. Chem. 1997, 69, 2653

20. Porat, Z.; Rubinstein, I.; Zinger, B.; J. Electrochem. Soc. 1993, 140, 2501

21. Bard, A.J.; Faulkner, L.; Electrochemical Methods, Wiley: New York, 2000

22. Daniele, S.; Ugo, P.; Bragato, C.; Mazzocchin, G.A.; J. Electroanal. Chem. 1996, 418, 29.

Received: February 29, 2003

Published on the web: August 8, 2003 